\title{
BOARDS OF DIRECTORS IN BRAZIL: LITERATURE REVIEW AND RESEARCH AGENDA $^{1}$
}

\author{
TOBIAS C. PARENTE2 \\ (iD) https://orcid.org/0000-0002-9162-4489 \\ CLÁUDIO A. P. MACHADO FILHO ${ }^{3}$ \\ (iD) https://orcid.org/0000-0002-6733-5142
}

To cite this paper: Parente, T. C., \& Machado, C. A. P., Filho (2020). Boards of directors in Brazil: Literature review and research agenda. Revista de Administração Mackenzie, 21(6), 1-31. doi:10.1590/1678-6971/eRAMD200066

Submission: Mar. 22, 2020. Acceptance: Aug. 18, 2020.

\footnotetext{
The authors thank the National Council for Scientific and Technological Development (Conselho Nacional de Desenvolvimento Científico e Tecnológico [CNPq]) for financing the research and Rafaela Almeida Cordeiro for the helpful comments and revisions of previous versions of the manuscript.

2 Ibirapuera University (UNIB), São Paulo, SP, Brazil.

3 University of São Paulo (USP), São Paulo, SP, Brazil.
}

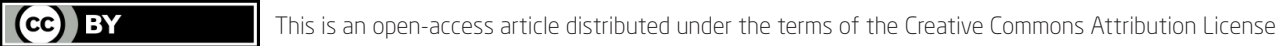

\footnotetext{
This paper may be copied, distributed, displayed, transmitted or adapted for any purpose, even commercially, if provided, in a clear and explicit way, the name of the journal, the edition, the year and the pages on which the paper was originally published, but not suggesting that RAM endorses paper reuse. This licensing term should be made explicit in cases of reuse or distribution to third parties.

Este artigo pode ser copiado, distribuído, exibido, transmitido ou adaptado para qualquer fim, mesmo que comercial, desde que citados, de forma clara e explícita, o nome da revista, a edição, o ano e as páginas nas quais o artigo foi publicado originalmente, mas sem sugerir que a RAM endosse a reutilização do artigo. Esse termo de licenciamento deve ser explicitado para os casos de reutilização ou distribuição para terceiros.
} 


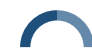

Tobias C. Parente, Cláudio A. P. Machado Filho

\section{ABSTRACT}

Purpose: The purpose of this paper is to review and systematize previous studies on boards of directors in Brazil and propose an agenda to guide future studies.

Originality/value: A conceptual model is developed to provide an integrated view for research on the board of directors, incorporating variables from different levels that connect governance mechanisms, best practices, board dynamics and company performance; we identified gaps for the research agenda.

Design/methodology/approach: This review analyzed 95 articles on boards of directors in Brazil between 2000 and 2019. The review was conducted in three major steps: 1 . planning; 2 . conducting; and 3. organizing the data and reporting the findings.

Findings: There is a growing interest in studying boards of directors in Brazil, with a wide range of topics. The most studied are board composition, best practices, diversity and gender. Despite the diversity, the previous studies are homogeneous in theoretical and methodological terms. Based on the agency theory, most articles sought to relate board demography to financial performance, and the findings are not convergent. This scenario opens up some research avenues to address topics that have not yet been explored, such as board processes, board tasks, and differentiation between board performance and company performance.

\section{KEYWORDS}

Board of directors. Corporate governance. Board member. Literature review. Research agenda. 


\section{INTRODUCTION}

The discussion about corporate governance (CG) in Brazil is still recent. The most heightened interest in the topic arose with the country's economic liberalization in the early 1990s. The entry of new investors, the privatization of state-owned enterprises, and the insertion of companies in the international market, among other factors, led Brazilian companies to organize their governance structures to respond to the new demands of the competitive environment.

This scenario aroused the interest of scholars in finance, management and accounting, and a new field of study has emerged in Brazil. While no article on CG had been published in Brazilian journals in the 1990s, in the following decade, 141 papers were published (Ribeiro, Muritiba, Muritiba, \& Domingues, 2012). As boards are the main structure of the corporate governance system, and, ultimately, are responsible for organizational effectiveness (Daily, Dalton, \& Cannella, 2003; Johnson, Daily, \& Ellstrand, 1996) and sustainable value creation (Huse, 2005), they drew the attention of Brazilian researchers.

Amid the novelty of boards for academics as well as for executives, investors, and regulators, several topics were studied, such as board contributions to financial performance (Almeida, Klotzle, \& Pinto, 2013; Condrige, Clemente, \& Espejo, 2012; Silveira, Barros, \& Famá, 2003), the importance of independent directors (Moura, Almeida, Vecchia \& Mazzioni, 2017; Santos, Orso, Lizote, \& Marcon, 2018), and CEO duality (Costa \& Martins, 2019; Dani, Kaveski, Santos, Leite, \& Cunha, 2017). These and other topics have been explored in studies in Brazil, and it is important to know what evidence has been accumulated. However, even though some previous works have revised the literature on CG in Brazil (e. g., Catapan \& Cherobim, 2010; Cunha, Moura, \& Santana, 2013; Kreuzberg \& Vicente, 2018; Ribeiro et al., 2012), we have not identified any that have focused exclusively on boards of directors.

Away from the Brazilian context, some literature reviews on boards have been published (e. g., Gabrielsson \& Huse, 2004; Johnson et al., 1996; Kagzi \& Guha, 2018; Krause, Semadeni, \& Cannella Jr., 2014; Petrovic, 2008; Zahra \& Pearce, 1989). These reviews demonstrate that most studies sought to relate the board's demographics, such as the presence of independent directors and women, with financial performance variables. Evidence suggests that the results are inconclusive and cannot demonstrate that there is a relationship between demographic variables and financial performance 
(Gabrielsson \& Huse, 2004; Van Ees, Gabrielsson, \& Huse, 2009; Zahra \& Pearce, 1989); therefore, this relationship is not as simple and direct as was thought, but instead complex and indirect (Boivie, Bednar, Aguilera, \& Andrus, 2016; Forbes \& Milliken, 1999). It is also possible to observe that studies are moving away from a macro view to addressing specific issues, such as gender (Kirsch, 2018), board involvement in strategic decision-making (Judge \& Talaulicar, 2017), board tasks (Åberg, Bankewitz, \& Knockaert, 2019), and family business boards (Bammens, Voordeckers, \& Van Gils, 2011).

These insights provide a reference for analyzing Brazilian studies since research on boards emerged in Brazil in 2000 and part of the knowledge produced was based on studies from other institutional environments. However, it should be noted that, over the years, the first Brazilian cases emerged, and it was possible to notice some particular characteristics, such as 1. high ownership concentration (Pinto \& Leal, 2013); 2. high participation of the state as a shareholder (Lazzarini, 2011); and 3. majority presence of family businesses (Aguilera, Kabbach de Castro, Lee, \& You, 2012). These and other characteristics may require specific designs for research on boards of directors in Brazil.

It is in this scenario that our study offers some contributions. To review and systematize previous studies on the board of directors in Brazil, we identified recurring theoretical and methodological patterns to propose a research agenda. Therefore, we developed a conceptual model that provides an integrated view, with variables that have still been little explored by Brazilian studies, such as psychosocial processes, board tasks, and differentiation between board-level outcomes and firm-level outcomes. Thus, this study contributes by addressing research gaps that can offer relevant contributions to the field of corporate governance.

This article is structured in five other sections. In the following section, we present the streams of research most adopted in studies on boards and our conceptual model. Next, methodological procedures are presented. Then, the results are described. In the following section, we analyze the results contrasting with the proposed conceptual model, and a research agenda is suggested. In the last section, we present the concluding remarks.

\section{THEORETICAL BACKGROUND}

The board of directors has been studied from different perspectives. To evaluate Brazilian studies, we observed the existing streams of research and developed a conceptual model that helps to reveal potential gaps for future research. 


\subsection{Streams of research}

When reviewing the studies on boards, Gabrielsson and Huse (2004) developed a taxonomy in which one axis of analysis is focused on the behavioral perspective and the other on the contingency perspective, as shown in Figure 2.1.1.

\section{(Figure 2.1.1)}

\section{TAXONOMY TO ANALYZE RESEARCH ON BOARDS}

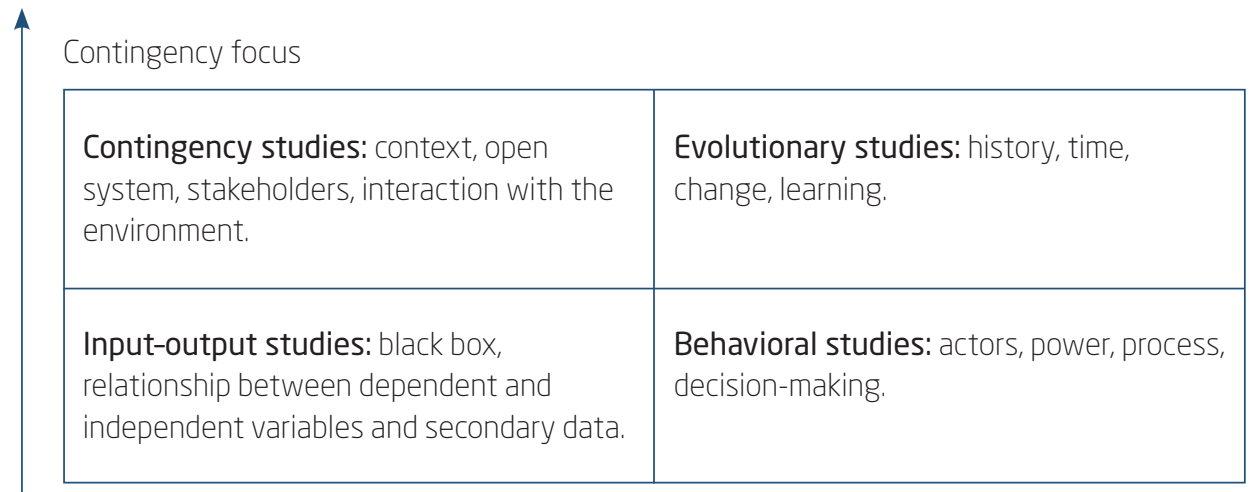

Behavioral focus

Source: Adapted from Gabrielsson \& Huse (2004).

- Input-output studies: These studies form the mainstream of research in CG. Its emergence is linked to the consolidation of agency theory as the main theoretical lens of CG studies (Dalton, Daily, Ellstrand, \& Johnson, 1998). Studies in this stream focus on corporations, and the governance problems investigated, in short, involve the misalignment of interests between executives and shareholders. The purpose of most articles is to investigate how boards can be responsible for a better financial performance. The justification is that boards, as the main internal CG mechanism, are responsible for monitoring executives and making them act in accordance with the interests of shareholders, which reduces agency costs and contributes to the financial performance.

Despite its widespread use, studies of this current have failed to reach conclusive results, and, in many cases, the findings have been controversial (Van Ees et al., 2009). The assumption that boards with an ideal composition would be able to raise the company's performance has not been proved by empirical studies. Because of this belief, much focus was 
given to board's control role, which proved to be superficial as a single factor to explain the financial performance (Daily et al., 2003; Zahra \& Pearce, 1989).

This scenario led boards to be considered a "black box," distant from society and difficult for researchers to access (Forbes \& Milliken, 1999; Huse, 2005; Leblanc \& Schwartz, 2007). Given the need to open the "black box," researchers made an appeal for future studies to explore the process singularities that involve board dynamics (Forbes \& Milliken, 1999; Rindova, 1999). Based on this, Gabrielsson and Huse (2004) proposed three other streams of research.

- Behavioral studies: The authors of this stream are interested in observing the actors, as well as the relationships and interactions among them, inside and outside the boardroom; processes that guide decision-making are explored. This stream emphasizes that charters and formal policies in organizations are not sufficient to fully understand CG (Gabrielsson $\&$ Huse, 2004). The logic of the argument is that boards can play several roles and establish different processes to act, and these may differ from stakeholder expectations (Forbes \& Milliken, 1999). Therefore, different theoretical lenses are needed to understand the board dynamics. Likewise, different data collection and analysis techniques are employed, although the survey is the most common (Gabrielsson \& Huse, 2004).

- Contingency studies: This stream considers the influence of contingencies and perspectives of multiple stakeholders on the boards, examining how the board's performance depends on the context in which the company is involved. The contingency studies look not only at the internal CG mechanisms, but also at the external ones (Aguilera, Desender, Bednar, \& Lee, 2015). CG is analyzed in a broad institutional and social environment in which the board's power is relative and depends on several factors, such as industry, legal regulations, and the development of relations between the various internal and external coalitions with an interest in the company, among others (Aguilera, Filatotchev, Gospel, \& Jackson, 2008). Governance systems are exploited mainly through contrasting theories and contexts. Data are collected in different ways, including archival data, surveys, and interviews (Gabrielsson \& Huse, 2004).

- Evolutionary studies: Studies of this stream explore context and behavior together. Scholars consider the governance system, as well as power and the attributes of internal and external actors, that can influence a board's decisions. Time and learning become relevant, which means that 
studies are designed with longitudinal data to understand the changes (Gabrielsson \& Huse, 2004). The evolutionary perspective can be treated as state of the art because it recognizes the need to consider the boards as open systems that may change and develop over time. This type of research, while being able to offer valuable contributions, is a great challenge for researchers, given the difficulty of operationalization.

\subsection{Integrated conceptual model}

There are different ways of conceptualizing boards within a CG system. In line with the input-output studies, the main one is that the board is a CG mechanism capable of mitigating agency conflict (Jensen \& Meckling, 1976). The board of directors, along with ownership, capital structure, and management incentives, make up the main internal CG mechanisms (Aguilera et al., 2015; Silveira, 2015). The interaction of these mechanisms with the board helps to understand how a board is composed and how it will act.

Despite the great interest in literature for internal mechanisms, they are not the only drivers of CG practices (Bueno, Nascimento, Lana, Gama, \& Marcon, 2018). There is a set of external mechanisms that influence governance, for example, legal systems, markets for corporate control, rating organizations, external audits, media, and stakeholder activism (Aguilera et al., 2015). These mechanisms also contribute to the establishment of best practices that guide the actions of governance agents.

Regarding the best practices recommended for the good functioning of boards, there is the board composition, which must include independent directors and a diversity of background among board members. In addition, the presence of executive-directors should be avoided, especially if the CEO is also the chair of the board. The argument is that a balanced composition helps board members to develop a synergic dynamic as a group and explore different viewpoints on relevant issues to the business.

As noted earlier, several studies have sought to investigate the relationship between board demographics and financial performance; however, they have failed to obtain consistent evidence (Boivie et al., 2016; Johnson et al., 1996; Zona \& Zattoni, 2007). A plausible explanation is that boards are characterized as groups that make complex, but sporadic decisions. As boards are not directly involved in implementing their decisions, the product they generate is fully cognitive (Forbes \& Milliken, 1999). For this reason, board effectiveness depends, to a large extent, on psychosocial processes and tasks that board members perform (Forbes \& Milliken, 1999; Zona 
\& Zattoni, 2007). Thus, the board's contribution to the firm's performance does not occur directly, but indirectly, through its decisions that affect the firm's activities and then can affect the firms' outcomes, as shown in Figure 2.2.1.

\section{(Figure 2.2.1)}

\section{CONCEPTUAL MODEL TO ANALYZE RESEARCH ON BOARDS OF DIRECTORS}

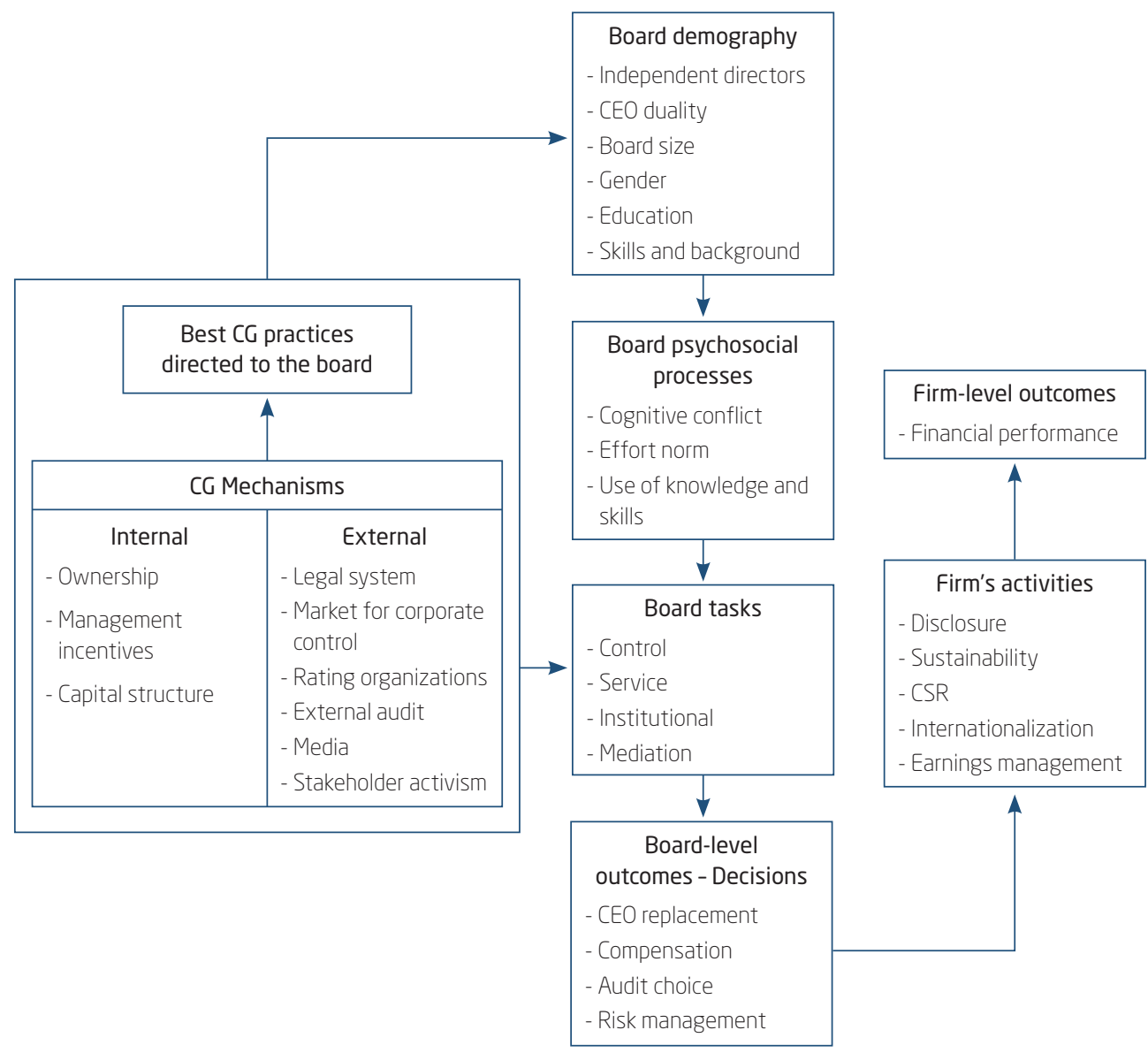

Source: Elaborated by the authors.

In Figure 2.2.1, it is possible to see that the board of directors' dynamics are influenced by other governance mechanisms (internal and external), which, in turn, influence the adoption of the best CG practices directed to the board. Thus, the board composition (demographics) is influenced by this interaction between mechanisms and CG practices. However, it is 
necessary to consider that both governance mechanisms and board demography are not directly related to the firm's outcomes; studies are needed to investigate the boards' dynamics to understand what makes them effective. Thus, boards came to be analyzed as a group that processes information to make decisions (Forbes \& Milliken, 1999; Leblanc \& Schwartz, 2007; van Ees et al., 2009).

The effectiveness of a group is the result of its psychosocial processes (Cohen \& Bailey, 1997). Processes are interactions, such as communication and conflicts, that occur between group members and other external participants, while psychosocial traits are shared understandings and group beliefs (Cohen \& Bailey, 1997). Among the psychosocial processes explored by the group effectiveness literature, three have been used to study the boards of directors: cognitive conflict, effort norms, and use of knowledge and skills.

Cognitive conflict refers to "disagreements among group members about the content of the tasks being performed, including differences in viewpoints, ideas, and opinions" (Jehn, 1995, p. 258). Cognitive conflict is highly likely to occur on boards. Due to the uncertainties inherent in the decision-making process, boards are always faced with ambiguous information that leads board members to have different points of view on the appropriate directions for each decision (Dutton \& Jackson, 1987). In addition, the board members have different experiences and knowledge (Zona \& Zattoni, 2007). Each board may experience different levels of cognitive conflict (Lorsch \& MacIver, 1989). The behavior of directors varies from "rubber stamping", which only endorses management decisions, to a more proactive style, developing structures and processes to promote constructive discussions (Zona \& Zattoni, 2007).

Effort norms refer to the beliefs shared by the group regarding the level of effort that is expected of each individual in carrying out a task (Wageman, 1995). As the directors are not recognized or rewarded for individual effort, it is expected that boards establish formal and informal norms to regulate the behavior of its members (Wageman, 1995). One of the main problems with this is that the time spent by the directors can vary widely (Lorsch \& MacIver, 1989). However, although the time spent is an important variable, Forbes and Milliken (1999) argue that it is not enough. Even boards that spend a similar amount of time in meetings exhibit different levels of effectiveness. The use of time and the proactive behavior of the board members depend, to a large extent, on the effort norms established by the group.

Use of knowledge and skills deals with the "board's ability to tap the knowledge and skills available to it and then apply them to its tasks" (Forbes 
\& Milliken, 1999, p. 495). Although there is an assumption that when knowledge and skills are present in a group, they will be used, research in psychology indicates that the availability of expertise in a group does not guarantee its use (Jackson, 1992). Therefore, a board should seek to integrate the knowledge and skills of the board members. In practical terms, these processes can occur through a flow of information among board members, a clear division of labor that assigns specific activities and tasks to the directors, and a delegation of tasks that considers the skills of each director (Forbes \& Milliken, 1999).

These and other processes influence how tasks are performed on boards. The literature has addressed four tasks more prominently: control, service, institutional, and mediation. The control task refers to the legal duty to monitor management on behalf of the company's shareholders and to fulfill this duty with sufficient loyalty and care (Monks \& Minow, 1995). The service task refers to its potential to provide advice to the CEO and other executives and to actively participate in strategic formulation (Forbes \& Milliken, 1999). In the institutional task, the board is the link between the company and its environment, facilitating access to critical resources for the business's success (Zona \& Zattoni, 2007). Finally, in the mediation task, the board coordinates interests, which may or may not be conflicting, between coalitions to reduce the complexity of the decision-making (Van Ees et al, 2009). In addition to psychosocial processes, the tasks performed by boards are influenced by the combination of governance mechanisms and CG practices. Board tasks can have internal and external focuses (Huse, 2005). Internally, the board must be able to monitor and provide management advice, while externally, it must control the company's conduct and use its networking to access resources. Focusing on one or more roles may depend on how internal and external governance mechanisms affect board tasks.

The combination of tasks with psychosocial processes is related to board effectiveness. However, as boards' decisions are the main product of their work (Forbes \& Miliken, 1999), one must consider that their effectiveness is linked to decision effectiveness. Nevertheless, board members are not responsible for implementing their decisions, which are carried out by managers. Thus, the effectiveness of their decisions depends on the activities that managers will conduct. A board decision on internationalization can only be effective if managers are able to execute it. For this, managers need guidance from the board. In this sense, there is no single recipe that companies can follow to make their boards effective and, as a result, perform better. The effectiveness of a board is the combination of certain factors that create a solution capable of making it effective in a given context. 


\section{METHODOLOGICAL PROCEDURES}

In this review, we followed the procedures suggested by Tranfield, Denyer, and Smart (2003) for conducting systematic reviews: 1. plan the review; 2. conduct the review; and 3. report and disseminate the review. In the planning phase, we defined the justification for carrying out this study and the questions that guide it. In the second step, we defined the criteria for identifying, selecting, and evaluating the studies, as well as synthesizing the extracted data. Finally, we organized the data to report it and propose a framework to guide future research.

The searches were carried out in three databases: Spell (contains articles from Brazilian journals), Scopus, and Web of Science. We found that the first paper about boards in Brazil was published in 2000 by the former chair of the board of the Brazilian Institute of Corporate Governance (IBGC), Bengt Hallqvist. Therefore, the analysis period comprises 20 years (20002019). The search and selection of studies were guided by four stages. First, to identify the papers, we used the words conselho de administração (board of directors) and board of directors. This procedure resulted in 438 studies (Spell - 315; Scopus - 88; Web of Science - 74). Second, after dealing with duplicates, we adopted two criteria to select those articles: 1. studies from management, finance, and accounting; and 2. studies from journals rated B2 or higher in Capes Qualis ${ }^{4}$. The number of articles was reduced to 179. It is important to note that only scientific papers were considered, disregarding book chapters and other materials returned by the search engines. Next, we analyzed the title and read the abstract of each study. At this stage, 73 articles were discarded, as the board of directors was not one of the central aspects of the study. Finally, we read the 106 articles and excluded 11 more because we believed that they also did not have the board of directors as a relevant aspect of the study, resulting in a total of 95 papers considered for this study.

The data were organized in an Excel spreadsheet, with information such as year, journal, authors, study topic, theoretical perspective, stream of research, methodological procedures, and variables. Given these pieces of information, we were able to report how research on boards of directors in Brazil has been developed and suggest some gaps for future studies.

This is a tool used to rate scientific journals in Brazil, which are framed in strata, indicating quality - A1, the highest; A2; B1; B2; B3; B4; B5 and C - no classification. 


\section{DESCRIPTIVE FINDINGS}

Descriptive information was organized into six categories: 1. evolution of studies over the years; 2 . journals; 3 . scholars; 4 . study topics; 5 . theoretical approaches; and 6. methodological aspects.

The interest in boards of directors in Brazil is growing. From 2000 to 2006 , only one or two articles were published per year; in 2019, there was a peak with 14 studies, as shown in Figure 4.1. Some factors contributed to this growth, including the creation of IBGC in 1999 and the creation of different listing segments of BOVESPA in 2000. Nevertheless, some studies have investigated how companies have been incorporating the recommendations of the IBGC code, while others have looked at whether the fact that companies are listed in segments could be related to any topic connected to the board.

\section{(Figure 4.1) \\ EVOLUTION OF STUDIES PER YEAR}

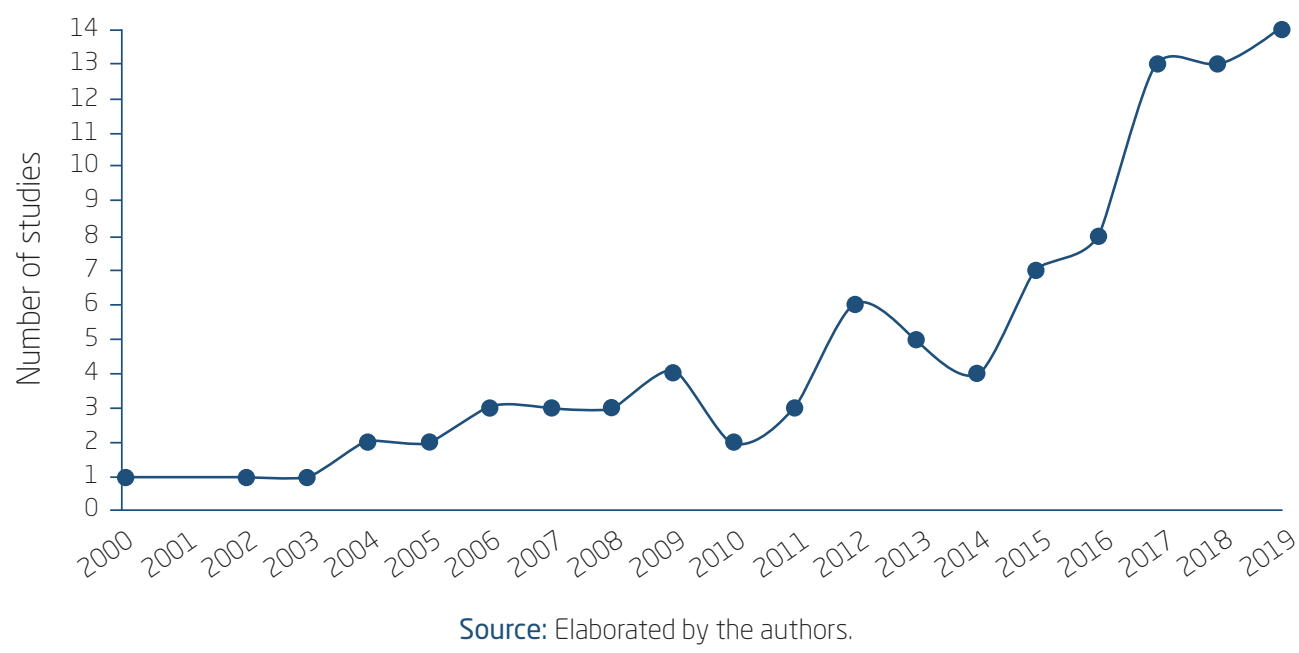

The studies are published in 45 different journals, 33 of which are published in Brazil and 12 are non-Brazilian. The journals that have published the most were the Revista de Administração Contemporânea (RAC) - eight; RAUSP Management Journal - six; Revista de Administração de Empresas (RAE) five; Revista Brasileira de Finanças - five; and Revista Contabilidade e Finanças - five. 
Regarding the authors, the studies had the collaboration of 208 different researchers, of which 167 contributed with one work, 28 had two articles, and 13 had three or more studies. These 13 researchers published 45 different studies, which represent $47.4 \%$ of the sample. Figure 4.2 presents the most productive scholars.

(Figure 4.2)

THE MOST PRODUCTIVE SCHOLARS

\begin{tabular}{ll}
\hline \multicolumn{1}{c}{ Scholars } & No studies \\
\hline Wesley Mendes-da-Silva & 7 \\
\hline Luciano Rossoni & 6 \\
\hline Rosilene Marcon & 6 \\
\hline Alexandre Di Miceli da Silveira & 5 \\
\hline Paulo Roberto da Cunha & 5 \\
\hline Joséte Florencio dos Santos & 4 \\
\hline Lucas Ayres Barreira de Campos Barros & 4 \\
\hline Orleans Silva Martins & 4 \\
\hline Andréia Carpes Dani & 3 \\
\hline Cláudio Antônio Pinheiro Machado Filho & 3 \\
\hline Fernanda Maciel Peixoto & 3 \\
\hline Ricardo Pereira Câmara Leal & 3 \\
\hline Richard Saito & 3 \\
\hline
\end{tabular}

Source: Elaborated by the authors.

Among the themes, there was great variation, with 26 different topics investigated. The most studied were board composition (25.3\%), CG quality $(13.7 \%)$, and gender and diversity (11.66\%), as shown in Figure 4.3. 


\section{(Figure 4.3)}

THE MAIN TOPICS STUDIED

\begin{tabular}{|c|c|}
\hline Topics & $\%$ \\
\hline Board composition & $25.3 \%$ \\
\hline CG quality & $13.7 \%$ \\
\hline Gender and diversity & $11.6 \%$ \\
\hline Board interlocking & $9.5 \%$ \\
\hline Compensation & $7.4 \%$ \\
\hline Disclosure & $6.3 \%$ \\
\hline Firm value & $5.3 \%$ \\
\hline CSR and sustainability & $5.3 \%$ \\
\hline Independent directors & $4.2 \%$ \\
\hline Foreign investment, foreign director, and internationalization & $4.2 \%$ \\
\hline Social capital & $3.2 \%$ \\
\hline Ownership structure & $3.2 \%$ \\
\hline Executive replacement & $3.2 \%$ \\
\hline Skills, roles, and strategic engagement of directors & $3.2 \%$ \\
\hline
\end{tabular}

Source: Elaborated by the authors.

It is important to note that the frequency of themes has varied over the years. In all the periods analyzed, board composition was always the first or the second in the rankings. The same occurred with CG quality; however, this theme was not widely studied between 2016 and 2019. During this period, the themes of board interlocking and gender and diversity were highlighted. It is worth mentioning that most studies on diversity observe the phenomenon by gender variables. In addition, the first study about gender and diversity was published in 2011 by Madalozzo. In addition to these themes, new topics were studied between 2016 and 2019, such as sustainability and social responsibility, foreign investment, foreign director and internationalization, and disclosure. More information is available in Figure 4.4 . 


\section{(Figure 4.4)}

THE MAIN TOPICS STUDIED BY PERIOD

\begin{tabular}{|c|c|c|}
\hline Period & Topics & $\mathrm{N}^{0}$ studies $^{*}$ \\
\hline \multirow{7}{*}{$\begin{array}{l}2000-2005 \\
\text { (7 studies) }\end{array}$} & Board composition & 3 \\
\hline & CG quality & 2 \\
\hline & Firm value & 1 \\
\hline & Independent directors & 1 \\
\hline & Ownership structure & 1 \\
\hline & Executive replacement & 1 \\
\hline & Skills, roles, and strategic engagement of directors & 1 \\
\hline \multirow{7}{*}{$\begin{array}{l}\text { 2006-2010 } \\
\text { (15 studies) }\end{array}$} & CG quality & 7 \\
\hline & Board composition & 5 \\
\hline & Board interlocking & 2 \\
\hline & Compensation & 1 \\
\hline & Firm value & 1 \\
\hline & Independent directors & 1 \\
\hline & Ownership structure & 1 \\
\hline \multirow{7}{*}{$\begin{array}{l}2011-2015 \\
\text { (25 studies) }\end{array}$} & Board composition & 5 \\
\hline & CG quality & 5 \\
\hline & Gender and diversity & 4 \\
\hline & Firm value & 3 \\
\hline & Compensation & 2 \\
\hline & Disclosure & 2 \\
\hline & Business efficiency & 2 \\
\hline \multirow{7}{*}{$\begin{array}{l}\text { 2016-2019 } \\
\text { (48 studies) }\end{array}$} & Board composition & 11 \\
\hline & Gender and diversity & 7 \\
\hline & Board interlocking & 6 \\
\hline & Compensation & 4 \\
\hline & Disclosure & 4 \\
\hline & Foreign investment, foreign director, and internationalization & 4 \\
\hline & CSR and sustainability & 4 \\
\hline
\end{tabular}

* The sum of the number of studies is not necessarily equal to the total number of articles published in the period because we considered only the most recurrent themes in each period and some studies dealt with more than one theme.

Source: Elaborated by the authors. 
In the theoretical approaches, as well as in the Gabrielsson and Huse's (2004) review, it is possible to identify a predominant approach in the analyzed studies: $72.6 \%$ have the agency theory as a theoretical reference, $55.8 \%$ consider control as one of the board's roles, and $90.5 \%$ are from the inputoutput stream. The information is summarized in Figure 4.5.

\section{(Figure 4.5)}

THEORIES, BOARD ROLES, AND STREAMS OF RESEARCH ADOPTED IN THE STUDIES

\begin{tabular}{lclc}
\multicolumn{1}{c}{ Streams of research } & $\%$ & \multicolumn{1}{c}{ Theories adopted } & $\%^{*}$ \\
\hline Input-output & $90.5 \%$ & Agency & $72.6 \%$ \\
\hline Behavioral & $5.3 \%$ & Resource dependence & $13.7 \%$ \\
\hline Contingency & $4.2 \%$ & Stakeholder & $11.6 \%$ \\
\hline Evolutionary & $0 \%$ & Social network & $10.5 \%$ \\
\hline \multicolumn{1}{c}{ Board roles } & $\% *^{*}$ & Resource-based view & $2.1 \%$ \\
\hline Control & $55.8 \%$ & Legalistic & $2.1 \%$ \\
\hline Service & $15.8 \%$ & Stewardship & $2.1 \%$ \\
\hline Strategic & $15.8 \%$ & Others & $9.5 \%$ \\
\hline Institutional & $3.2 \%$ & Theory not identified & $17.9 \%$ \\
\hline Mediation & $2.1 \%$ & & \\
\hline Others & $3.2 \%$ & & \\
\hline Role not identified & $41.1 \%$ & & \\
\hline
\end{tabular}

* Total percentage is greater than $100 \%$, as some studies adopted more than one theory and addressed more than one board role.

As in the theoretical approach, the methodological strategies adopted also have a recurring pattern. In short, $98.9 \%$ of the studies are empirical, most of which are exclusively quantitative with the use of secondary data. Less than $10 \%$ of the empirical studies were conducted with data collected directly from board members and other governance agents. Despite the quantitative predominance, only $46.6 \%$ of these studies presented hypotheses. Observing the contributions, $64.2 \%$ of all studies did not explicitly present the contribution of the study throughout the text, whether theoretical, practical, or methodological. The results are summarized in Figure 4.6. 


\section{(Figure 4.6)}

THE MAIN METHODOLOGICAL ASPECTS

\begin{tabular}{lcclcc}
\multicolumn{1}{c}{ Research type } & $\mathrm{n}=95$ & $\%$ & Contributions & $\mathrm{n}=95$ & $\%$ \\
\hline Empirical & 94 & $98.9 \%$ & No & 61 & $64.2 \%$ \\
\hline Other & 1 & $1.1 \%$ & Yes & 34 & $35.8 \%$ \\
\hline \multicolumn{1}{c}{ Research nature } & $\mathrm{n}=95$ & $\%$ & \multicolumn{1}{c}{ Data $^{*}$} & $\mathrm{n}=94^{\star}$ & $\%$ \\
\hline Quantitative & 87 & $91.5 \%$ & Secondary & 85 & $90.4 \%$ \\
\hline Qualitative & 6 & $6.3 \%$ & Primary & 9 & $9.6 \%$ \\
\hline Qualitative-quantitative & 1 & $1.1 \%$ & Hypotheses & $\mathrm{n}=88^{\star *}$ & $\%$ \\
\hline Essaty & 1 & $1.1 \%$ & No & 47 & $53.4 \%$ \\
\hline & & & Yes & 41 & $46.6 \%$ \\
\hline
\end{tabular}

* Considered only empirical studies.

** Considered only qualitative studies.

Source: Elaborated by the authors.

Considering the variables adopted, 50 different independent and 40 dependent variables were identified. The researchers have a preference for dependent variables that are associated with the firm's performance or financial indicators; the three most used were Tobin's q (18.9\%), ROA $(14.7 \%)$, and ROE (11.6\%). Regarding the independent variables, there is the presence/percentage of independent and external directors (57.9\%), board size $(51.6 \%)$, and CEO duality (45.3\%). The main variables are shown in Figure 4.7.

\section{(Figure 4.7)}

THE MAIN VARIABLES USED IN STUDIES

\begin{tabular}{llll}
\multicolumn{1}{c}{ Independent } & Variables & & \\
\hline \multicolumn{1}{c}{ Independent and external directors } & $57.9 \%$ & Tobin's q & Dependent \\
\hline Board size & $51.6 \%$ & ROA & $18.9 \%$ \\
\hline CEO duality & $45.3 \%$ & ROE & $14.7 \%$ \\
\hline Gender & $22.1 \%$ & Compensation & $11.6 \%$ \\
\hline Shares of major shareholders & $16.8 \%$ & Disclosure & $8.4 \%$ \\
\hline
\end{tabular}




\section{(Figure 4.7 (conclusion))}

THE MAIN VARIABLES USED IN STUDIES

\begin{tabular}{|c|c|c|c|}
\hline \multicolumn{4}{|c|}{ Variables } \\
\hline Independent & $\%^{*}$ & Dependent & $\%$ \\
\hline Board committees & $14.7 \%$ & Market-to-book & $6.3 \%$ \\
\hline Directors' age & $12.6 \%$ & Corporate debt & $5.3 \%$ \\
\hline Board interlocking & $12.6 \%$ & Board interlocking & $3.2 \%$ \\
\hline Directors' tenure & $11.6 \%$ & CG quality & $3.2 \%$ \\
\hline Directors' education & $11.6 \%$ & & \\
\hline
\end{tabular}

* Total percentage is greater than $100 \%$, as some studies adopted more than one independent variable.

\section{INTEGRATED ANALYSIS AND RESEARCH AGENDA}

In this section, we analyze how Brazilian studies covered the relationships proposed in the model presented in the literature review, as shown in Figure 5.1. Based on this, we identify the research gaps and propose an agenda for future studies.

Analyzing the studies, it is possible to identify that research in Brazil is quite homogeneous. With some exceptions, most studies sought to relate board demography to firm performance. Depending on the study proposal, some other perspectives were considered, such as board decisions, company activities, internal CG mechanisms, and best CG practices. As reported in other reviews (e. g., Gabrielsson \& Huse, 2004; Johnson et al., 1996; Zahra $\&$ Pearce, 1989), the relationship between demography and financial performance failed to produce convergent results in Brazil.

Regarding the presence of women on boards, Almeida et al. (2013) and Costa, Sampaio, and Flores (2019) found a negative relationship between the percentage of seats occupied by women and ROE, while Carvalhal da Silva and Margem (2015) showed that this relationship is not significant. Conversely, Magro, Carpes, Vergini, and Silva (2018) found a positive relationship. Regarding board size, Silveira et al. (2003) showed that there is an optimal size (between five and six members), which is related to Tobin's q, while Condrige et al. (2012) found a positive correlation between board size and firm performance. Condrige et al. (2012) also observed a correlation absence between board independence and Tobin's q, while Silveira et al. 
(2003) found a positive relationship. In turn, the study by Black, Carvalho, and Gorga (2012) shows that greater board independence predicts a low Tobin's q. Finally, Almeida et al. (2013), Dani et al. (2017), and Santos et al. (2018) found positive, but not significant, relationships.

Considering companies' activities and boards' decision-making, it is not possible to identify a pattern. However, there are interesting results from studies that have been dealing with themes that need to be further explored. Regarding compensation, for example, the results of Brandão, Vasconcelos, Luca, and Crisóstomo (2019) indicate that the proportion of executives and independent members on boards reduces the pay-performance sensitivity (PPS), a measure of executive compensation effectiveness made operational by the relationship between increasing manager remuneration and increasing the company's market value. In terms of remuneration, Alves and Leal (2016) also found that more homogeneous and passive boards could grant higher remuneration. Another topic that received attention was disclosure. Bueno, Marcon, Pruner-da-Silva, and Ribeirete (2018) observed that the presence of women on the board has a positive relationship with voluntary disclosure, while the CEO duality has a negative effect. For the environmental disclosure, independent directors have a positive relationship, according to Fernandes, Bornia, and Nakamura (2019).

These results indicate that the relationship between board demography and firm performance is not simple and direct, but complex and indirect (Boivie et al., 2016; Forbes \& Milliken, 1999; Johnson et al., 1996; Zahra \& Pearce, 1989). They also demonstrate that demographic variables have little power to explain business activities and decisions. One justification is that, although they explore relevant issues, the Brazilian studies have the same research design of input-output studies. One of the features of these studies is that they explore research questions that help identify "what" occurs, but few explored "how" and "why" the phenomena take place within the board rooms.

In addition, there are two other justifications for why input-output studies do not present direct and convergent results. First, the studies depart from the assumption that there are "one size fits all" CG practices that are applicable to all companies. However, the incorporation of CG practices depends on the environment in which the company operates and its trajectory. Thus, different companies can adopt different CG practices (Aguilera \& Jackson, 2003). Second, when examining only outcomes at the firm-level, especially financial performance, studies do not consider that the implementation of CG practices, especially at the board-level, depend on the group 


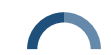

Tobias C. Parente, Cláudio A. P. Machado Filho

and individual-level outcomes (Gabrielsson \& Huse, 2004; Nicholson \& Kiel, 2004; Petrovic, 2008).

The studies analyzed in this review do not address the individual and group levels. One explanation for the absence of such studies is the difficulty of access. This is what makes the boards of directors a "black box" (Huse, 2005; Leblanc \& Schwartz, 2007). To help open this "black box," we suggest five research gaps (RG) to be addressed by future studies, as shown in Figure 5.1.

\section{(Figure 5.1)}

\section{CONCEPTUAL MODEL TO ANALYZE RESEARCH ON BOARDS OF DIRECTORS IN BRAZIL AND RESEARCH GAPS}

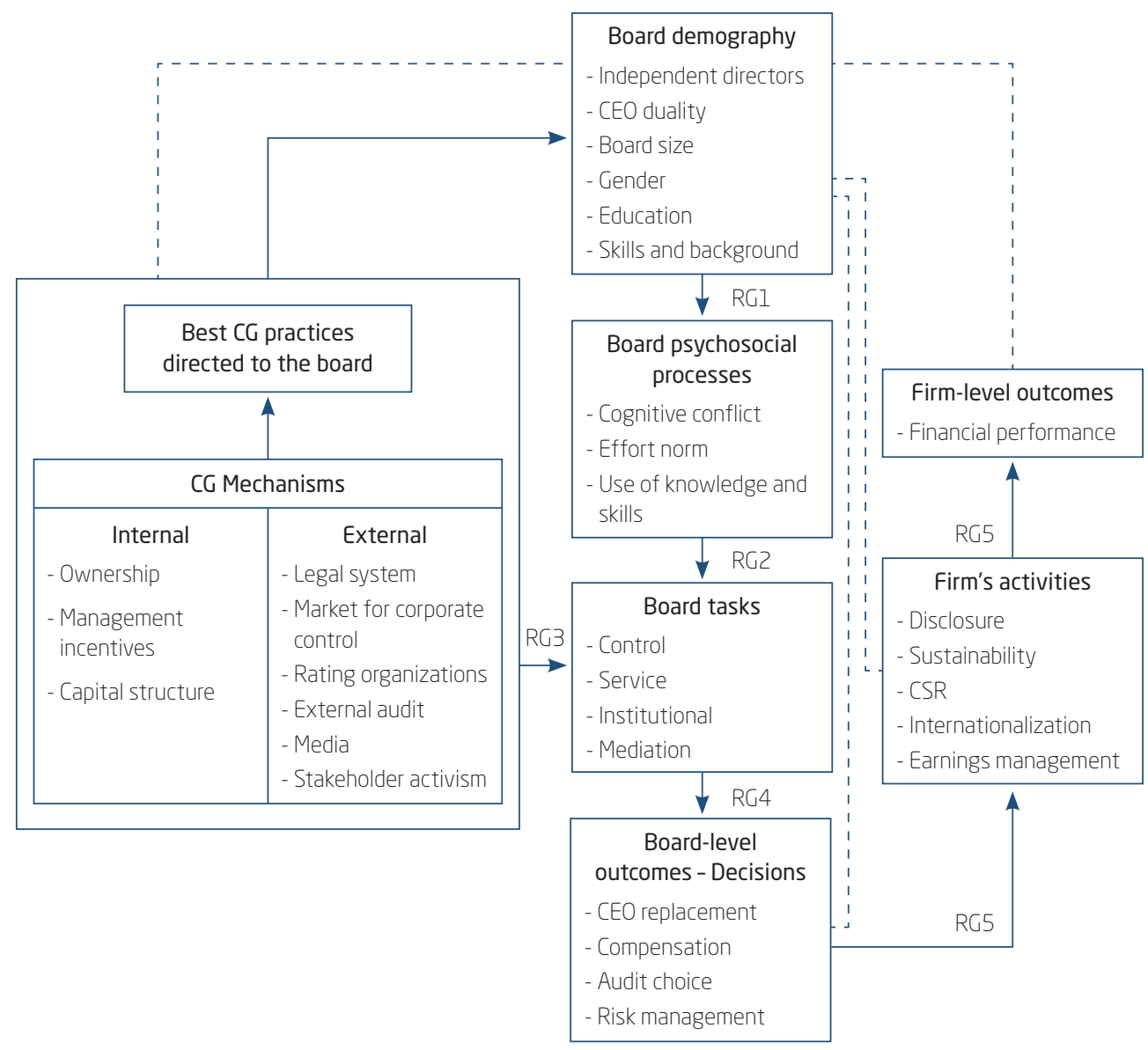

--- Relationships explored by Brazilian studies.

RG - Research gap. 
- $\quad$ RG1 - Demography and psychosocial processes: Despite boards being a sporadic group that gathers and processes information (Forbes \& Miliken, 1999), none of the studies analyzed sought to investigate questions regarding psychosocial processes. Among the various possibilities to be explored, we highlight two: the role of women and independent directors. Previous research has shown an interest in showing that the presence of women and independent directors has a positive relationship with the company's outcomes. However, we know little about how the presence of these directors influences the board dynamics. As proposed by Forbes and Milliken (1999), there are specific board processes that contribute to its effectiveness as a group and, consequently, to the organization's performance. According to the authors, these processes mediate the relationship between the board demography and the firm's performance. In other words, for the board composition to influence the firm's performance, it is necessary for the board to develop psychosocial processes that make it capable of being effective in the performance of its tasks. Therefore, before relating the presence of women and independent directors to performance variables, we need to understand how these directors influence, at the group-level, cognitive conflict, effort norms, and the use of knowledge and skills of all board members.

Researchers have the opportunity to identify how this occurs in different topics relevant to the board, such as remuneration, internationalization, sustainability, and disclosure. In addition, it is important to identify the contribution of these directors when the issues are of greater or lesser interest to the controlling shareholder or relevant stakeholders.

- RG2 - Psychosocial processes and board tasks: Although Martins and Rodrigues (2005) addressed different board tasks in their study and other studies consider the institutional task when exploring the phenomenon of board interlocking, no study has observed the relationships between psychosocial processes and board tasks. In empirical terms, there is evidence of a positive relationship between the board task performance and psychosocial processes (Minichilli, Zattoni, Nielson, \& Huse, 2012; Zona \& Zattoni, 2007). In addition, Minichilli et al. (2012) revealed that some processes, such as the use of knowledge and skills, are predictive variables, regardless of the institutional environment in which the organization operates.

This observation is important since research on boards has produced results directed to a specific set of companies, in general, publicly-held corporations (Bammens et al., 2011). Nevertheless, "most previous governance studies have been criticized for either adopting under- or 
over-contextualized views" (Minichilli et al., 2012, p. 193). Therefore, it is necessary to understand how the relationship between the processes and board tasks occurs in other contexts. Brazil has characteristics arising from its economic and cultural formation that make the institutional environment different from that of the developed countries. The economic development of Brazil was marked by strong local protectionism and state intervention in the economy, both as a regulator and a shareholder (Lazzarini, 2011). Brazilian culture has strong collectivist, paternalistic traits and a peculiar aspect, which is often called "jeitinho brasileiro" (Brazilian way), suggesting that informal relationships may be more important than formal ones (Caldas, 2006). These characteristics can affect board dynamics in Brazil and deserve to be explored.

- $\quad$ RG3 - CG mechanisms and board tasks: In line with research from other countries, CG mechanisms are extensively explored by Brazilian studies, especially with regard to the ownership structure; however, little attention has been paid to board tasks. In addition, we have not identified studies that relate to boards and external CG mechanisms. This gap can be a fertile field for future research, mainly because most Brazilian companies have a family controlling shareholder (Aguilera et al., 2012; Black, Carvalho, \& Gorga, 2010). Family firms seek to achieve not only the economic goals related to the business, but also to meet the family goals (Gómez-Mejía, Haynes, Núñez-Nickel, Jacobson, \& MoyanoFuentes, 2007) and family members, even if they are not shareholders, can influence business decisions (Mitchell, Agle, Chrisman, \& Spence, 2011); therefore, the board's tasks may not be limited to management control. The boards of family businesses, especially those that are privately held, may be responsible for reducing information asymmetry among the various family units and for maintaining the firm as a family business over the generations (Bammens et al., 2011). In this sense, researchers can explore how the board of directors, especially when there are independent members, deals with pressures from external governance mechanisms, such as family members who do not participate in the business.

- RG4 - Tasks and board outcomes: Most of the studies were interested in the firm's outcomes; however, almost none explored the board outcomes as a group. This perspective is fundamental, since board members are not responsible for executing their decisions. The board outcomes and the decisions are dependent on the board's ability to perform its tasks (Forbes \& Miliken, 1999; Zona \& Zattoni, 2007). In addition, developing objective measures of board performance is one of the main challenges 
for advancing research (Åberg et al., 2019). Therefore, understanding how these roles are required for different types of decisions is an opportunity for future studies. It is not necessarily the control role, as predicted by agency theory, that will provide the best decision. Thus, researchers can seek to understand what dominates the board dynamics for different decisions (remuneration, CEO replacement, audit choice, risk management etc.) in different firms, such as State-owned enterprises, family businesses, and multinationals.

- RG5 - Board-level and firm-level outcomes: As we argued previously, it needs to be clear that the outcomes at the firm-level are not necessarily synonymous with the outcomes at the board-level. Since the product generated by boards is cognitive, their outcomes need to be assessed based on their decisions. The board decision effectiveness is the result of the decision-making process, which is based on the idea that different processes lead to different choices, and different choices lead to different results (Dean \& Sharfman, 1996). Even if it is related, decision-making and choices are different concepts. The decision-making process refers to what people do to support their decisions, for example, analysis of available information, while the choice is the explanation of why one alternative was selected at the expense of others. The decision-making process is considered effective when it generates appropriate choices to the objectives established by decision-makers. Therefore, a decision is considered effective when it reaches or exceeds the objectives established during the decision-making process (Dean \& Sharfman, 1996). The decision may or may not cause positive outcomes for the company because even if board members make appropriate choices, it is necessary to consider the firm's characteristics and the external environment (Elbanna \& Child, 2007).

Understanding this relationship between decision-making process, board decisions, and firm outcomes is essential. We still know little about how to ensure that board decision-making produces effective decisions and, therefore, beneficial outcomes for the firm. Future studies can provide important contributions in exploring the board-level outcomes from the observation of the decision-making process.

\section{CONCLUDING REMARKS}

The number of studies about boards of directors has grown in Brazil. However, they are still homogeneous in terms of theory and method. 
Through this review, it is clear that there are opportunities for considerable progress in studies on boards of directors in Brazil. To contribute to this work, we sought to organize and analyze existing knowledge, placing previous studies in an integrative model. Thus, it was possible to propose a research agenda with potential avenues to be explored.

Future studies should seek to go beyond the input-output stream. New research designs are needed to consider not only variables at the firm level, such as financial performance, but also at the board-level and individuallevel. Our conceptual model and the research gaps that we highlighted may help researchers develop innovative studies that combine multiple levels of analysis and move the board research in Brazil beyond the "one size fits all" general recommendations of best CG practices. Thus, we hope that the elements put forth in this review can contribute to future research seeking to understand not only "what" occurs on boards of directors, but also "how" and "why" phenomena occur inside the boardrooms.

\section{CONSELHOS DE ADMINISTRAÇÃO NO BRASIL: REVISÃO DA LITERATURA E AGENDA DE PESQUISA}

\section{RESUMO}

Objetivo: Este artigo tem como objetivos revisar e sistematizar os estudos anteriores em conselho de administração no Brasil e propor uma agenda para orientar futuras pesquisas.

Originalidade/valor: Foi desenvolvido um modelo conceitual que fornece uma visão integrada para a pesquisa em conselho de administração. A partir de uma análise com variáveis de diferentes níveis que conectam os mecanismos de governança, boas práticas de governança, dinâmica do conselho e resultados da empresa, identificaram-se as lacunas para a agenda de pesquisa.

Design/metodologia/abordagem: Esta revisão analisou 95 artigos sobre conselhos de administração no Brasil publicados no período de 2000 a 2019. A revisão foi desenvolvida em três etapas: 1. planejamento, 2. condução e 3. organização dos dados e reporte dos resultados.

Resultados: O interesse por estudar conselhos de administração no Brasil é crescente, com uma grande diversidade de temas. Os tópicos mais estudados são: composição do conselho; boas práticas de GC; diversidade 
e gênero. Apesar dos diferentes temas, os trabalhos são homogêneos em termos teóricos e metodológicos. Baseada na teoria da agência, a maioria dos artigos buscou relacionar variáveis demográficas do conselho com o desempenho empresarial, e os resultados encontrados não são convergentes. Esse cenário abre oportunidades de pesquisas para endereçar temas ainda não explorados, como: processos psicossociais, tarefas do conselho e diferenciação entre resultados do conselho e resultados da empresa.

\section{$\int$ PALAVRAS-CHAVE}

Conselho de administração. Governança corporativa. Conselheiro de administração. Revisão da literatura. Agenda de pesquisa.

\section{REFERENCES}

Åberg, C., Bankewitz, M., \& Knockaert, M. (2019). Service tasks of board of directors: A literature review and research agenda in an era of new governance practices. European Management Journal, 37(5), 648-663. doi:10.1016/j.emj.2019.04.006

Aguilera, R. V., Desender, K., Bednar, M. K., \& Lee, J. H. (2015). Connecting the dots: Bringing external corporate governance into the corporate governance puzzle. The Academy of Management Annals, 9(1), 483-573. doi:10.1080/19416520.2015.1024503

Aguilera, R. V., Filatotchev, I., Gospel, H., \& Jackson, G. (2008). An organizational approach to comparative corporate governance: Costs, contingencies and complementarities. Organization Science, 19(3), 475-492. doi:10.1287/ orsc. 1070.0322

Aguilera, R. V., \& Jackson, G. (2003). The cross nation-diversity of corporate governance: Dimensions and determinants. Academy of Management Review, 28(3), 447-465. doi: 10.5465/amr.2003.10196772

Aguilera, R. V., Kabbach de Castro, L. R., Lee, J. H., \& You, J. (2012). Corporate governance in emerging markets. In G. Morgan \& R. Whitley (Eds.), Capitalisms and capitalism in the 21st century (pp. 319-344). Oxford: Oxford University Press. 
Almeida, R. S., Klotzle, M. C., \& Pinto, A. C. (2013). Composição do conselho de administração no setor de energia elétrica do Brasil. Revista de Administração da UNIMEP, 11 (1), 156-180. doi:10.15600/1679-5350/rau. v11n1p156-180

Alves, M. B., \& Leal, R. P. (2016). Board characteristics and compensation in Brazilian listed companies. International Journal of Disclosure and Governance, 13(4), 309-328. doi:10.1057/jdg.2016.3

Bammens, Y., Voordeckers, W., \& Van Gils, A. (2011). Boards of directors in family businesses: A literature review and research agenda. International Journal of Management Reviews, 13(2), 134-152. doi:10.1111/j.1468-2370. 2010.00289.x

Black, B. S., Carvalho, A. G., \& Gorga, E. (2010). Corporate governance in Brazil. Emerging Markets Review, 11 (1), 21-38. doi:10.1016/j.ememar.2009. 09.004

Black, B. S., Carvalho, A. G., \& Gorga, E. (2012). What matters and for which firms for corporate governance in emerging markets? Evidence from Brazil (and other BRIK countries). Journal of Corporate Finance, 18(4), 934-952. doi:10.1016/j.jcorpfin.2011.10.001

Boivie, S., Bednar, M. K., Aguilera R. V., \& Andrus, J. L. (2016). Are boards designed to fail? The implausibility of effective board monitoring. The Academy of Management Annals, 10(1), 319-407. doi:10.5465/19416520. 2016.1120957

Brandão, I. D. F., Vasconcelos, A. C. D., Luca, M. M. M. D., \& Crisóstomo, V. L. (2019). Composition of the board of directors and pay-performance sensitivity. Revista Contabilidade \& Finanças, 30(79), 28-41. doi:10.1590/ 1808-057x201806610

Bueno, G., Marcon, R., Pruner-da-Silva, A. L., \& Ribeirete, F. (2018). The role of the board in voluntary disclosure. Corporate Governance: The International Journal of Business in Society, 18(5), 886-910. doi:10.1108/CG-09-2017-0205 Bueno, G., Nascimento, K., Lana, J., Gama, M. A. B., \& Marcon, R. (2018). Mecanismos externos de governança corporativa no Brasil. Revista Contabilidade, Gestão e Governança, 21 (1), 120-141.

Caldas, M. (2006). Conceptualizing Brazilian multiple and fluid cultural profiles. Management Research, 4(3), 169-180. doi:10.2753/JMR1536-5433 040303

Carvalhal da Silva, A. L., \& Margem, H. (2015). Mulheres em cargos de alta administração afetam o valor e desempenho das empresas brasileiras? Revista Brasileira de Finanças, 13(1), 102-133. doi:10.12660/rbfin.v13n1. 2015.35116 
Catapan, A., \& Cherobim, A. P. M. S. (2010). Estado da arte da governança corporativa: Estudo bibliométrico nos anos de 2000 a 2010. Revista de Administração, Contabilidade e Economia, 9(1-2), 207-230.

Cohen, S. G., \& Bailey, D. E. (1997). What makes teams work: Group effectiveness research from the shop floor to the executive suite. Journal of Management, 23(3), 239-290. doi:10.1177/014920639702300303

Condrige, E. O., Clemente, A., \& Espejo, M. M. S. B. (2012). Estrutura do conselho de administração e valor das companhias brasileiras. Brazilian Business Review, 9(3), 72-95.

Costa, L., Sampaio, J. D. O., \& Flores, E. S. (2019). Diversidade de gênero nos conselhos administrativos e sua relação com desempenho e risco financeiro nas empresas familiares. Revista de Administração Contemporânea, 23(6), 721-738. doi:10.1590/1982-7849rac2019180327

Costa, Y. C. L., \& Martins, O. S. (2019). CEO duality and corporate performance: evidence in the Brazilian capital market. Revista de Administração da UFSM, 12 (3), 403-417. doi:10.5902/1983465919515

Cunha, P. R., Moura, G. D., \& Santana, A. G. (2013). Perfil dos estudos sobre o tema governança corporativa publicados em periódicos brasileiros de 2009 a 2011. Registro Contábil, 4(2), 105-122.

Daily, C. M., Dalton, D. R., \& Cannella, A. A. (2003). Corporate governance: Decades of dialogue and data. Academy of Management Review, 28(3), 371-382. doi:10.5465/AMR.2003.10196703

Dalton, D. R., Daily, C. M., Ellstrand, A. E., \& Johnson, J. L. (1998). Metaanalytic reviews of board composition, leadership structure, and financial performance. Strategic Management Journal, 19(3), 269-290. doi:10.1002/ (SICI) 1097-0266(199803) 19:3<269::AID-SMJ950>3.0.CO;2-K

Dani, A. C., Kaveski, I. D. S., Santos, C. A. dos, Leite, A. P. P., \& Cunha, P. R. da (2017). Características do conselho de administração e o desempenho empresarial das empresas listadas no novo mercado. Revista de Gestão, Finanças e Contabilidade, 7(1), 29-47. doi:10.18028/2238-5320/rgfc.v7 n1p29-47

Dean, J. W., \& Sharfman, M. P. (1996). Does decision process matter? A study of strategic decision-making effectiveness. Academy of Management Journal, 39(2), 368-396. doi:10.5465/256784

Dutton, J., \& Jackson, S. (1987). Categorizing strategic issues: Links to organizational action. Academy of Management Review, 12 (1), 76-90. doi:10. $2307 / 257995$ 
Elbanna, S., \& Child, J. (2007). Influences on strategic decision effectiveness: Development and test of an integrative. Strategic Management Journal, 28(4), 431-453. doi:10.1002/smj.597

Fernandes, S. M., Bornia, A. C., \& Nakamura, L. R. (2018). The influence of boards of directors on environmental disclosure. Management Decision, 57(9), 2358-2382. doi:10.1108/MD-11-2017-1084

Forbes, D. P., \& Milliken, F. J. (1999). Cognition and corporate governance: Understanding boards of directors as strategic decision-making groups. Academy of Management Review, 24(3), 489-505. doi:10.5465/amr.1999. 2202133

Gabrielsson, J., \& Huse, M. (2004). Context, behavior, and evolution: Challenges in research on boards and governance. International Studies of Management and Organization, 34(2), 11-36. doi:10.1080/00208825.2004.1 1043704

Gómez-Mejía, L. R., Haynes, K. T., Núñez-Nickel, M., Jacobson, K. J. L., \& Moyano-Fuentes, J. (2007). Socioemotional wealth evidence from Spanish olive oil mills. Administrative Science Quarterly, 52 (1), 106-137. doi:10.2189/ asqu.52.1.106

Hallqvist, B. (2000). Código das melhores práticas de governança corporativa - O conselho de administração. Revista de Administração, 35(2), 72-76.

Huse, M. (2005). Accountability and creating accountability: A framework for exploring behavioural perspectives of corporate governance. British Journal of Management, 16(1), 65-79. doi:10.1111/j.1467-8551.2005.00448.x

Jackson, S. (1992). Consequences of group composition for the interpersonal dynamics of strategic issue processing. In J. Dutton, A. Huff, \& P. Shrivastava (Eds.), Advances in strategic management (Vol. 8, pp. 345-382). Greenwich, CT: JAI Press.

Jehn, K. A. (1995). A multimethod examination of the benefits and detriments of intragroup conflict. Administrative Science Quarterly, 40(2), 256-282. doi: $10.2307 / 2393638$

Jensen, M. C., \& Meckling, W. H. (1976). Theory of the firm: Managerial behavior, agency costs and ownership structure. Journal of Financial Economics, 3(4), 305-360. doi:10.1016/0304-405X(76)90026-X

Johnson, J. L., Daily, C. M., \& Ellstrand, A. E. (1996). Boards of directors: A review and research agenda. Journal of Management, 22 (3), 409-438. doi:10.1177/014920639602200303 
Judge, W. Q., \& Talaulicar, T. (2017). Board involvement in the strategic decision making process: A comprehensive review. Annals of Corporate Governance, 2(2), 51-169. doi:10.1561/109.00000005

Kagzi, M., \& Guha, M. (2018). Board demographic diversity: A review of literature. Journal of Strategy and Management, 11(1), 33-51. doi:10.1108/ JSMA-01-2017-0002

Kirsch, A. (2018). The gender composition of corporate boards: A review and research agenda. The Leadership Quarterly, 29(2), 346-364. doi:10.1016/j. leaqua.2017.06.001

Krause, R., Semadeni, M., \& Cannella, A. A., Jr. (2014). CEO duality: A review and research agenda. Journal of Management, 40(1), 256-286. doi:10.1177/0149206313503013

Kreuzberg, F., \& Vicente, E. F. R. (2018). Para onde estamos caminhando? Uma análise das pesquisas em governança corporativa. Revista de Administração Contemporânea, 23(1), 43-66. doi:10.1590/1982-7849rac2019170381

Lazzarini, S. G. (2011). Capitalismo de laços: Os donos do Brasil e suas conexões. São Paulo: Campus.

Leblanc, R., \& Schwartz, M.S. (2007). The black box of board process: Gaining access to a difficult subject. Corporate Governance: An International Review, 15(5), 843-851. doi:10.1111/j.1467-8683.2007.00617.x

Lorsch, J. W., \& MacIver, E. (1989). Pawns or potentates: The reality of America's corporate boards. Boston, MA: Harvard Business School Press.

Madalozzo, R. (2011). CEOs e composição do conselho de administração: a falta de identificação pode ser motivo para existência de teto de vidro para mulheres no Brasil? Revista de Administração Contemporânea, 15(1), 126-137. doi:10.1590/S1415-65552011000100008

Magro, C. B., Carpes, A. D., Vergini, D., \& Silva, M. Z. (2018). Glass ceiling em cargos de board e seu impacto no desempenho organizacional. Revista Contemporânea de Contabilidade, 15(34), 158-180. doi:10.5007/21758069.2018v15n34p158

Martins, H. C., \& Rodrigues, S. B. (2005). Atributos e papéis dos conselhos de administração das empresas brasileiras. Revista de Administração de Empresas, 45(ed. esp.), 23-35. doi:10.1590/S0034-75902005000500002

Minichilli, A., Zattoni, A., Nielson, D., \& Huse, M. (2012). Board task performance: An exploration of micro- and macro-level determinants of board effectiveness. Journal of Organizational Behavior, 33(2), 193-215. doi:10.1002/job.743 
Mitchell, R. K., Agle, B. R., Chrisman, J. J., \& Spence, L. J. (2011). Toward a theory of stakeholder salience in family firms. Business Ethics Quarterly, 21 (2), 235-255. doi:10.5840/beq201121215

Monks, R., \& Minow, N. (1995). Corporate governance. Cambridge, MA: Blackwell.

Moura, G. D., Almeida, I. X., Vecchia, L. A., \& Mazzioni, S. (2017). Influence of board independence on earnings management. Journal of Accounting, Management and Governance, 20(3), 370-391. doi:10.21714/1984-3925_ 2017v20n3a4

Nicholson, G. J., \& Kiel, G. C. (2004). A framework for diagnosing board effectiveness. Corporate Governance: An International Review, 12 (4), 442-460. doi:10.1111/j.1467-8683.2004.00386.x

Petrovic, J. (2008). Unlocking the role of a board director: A review of the literature. Management Decision, 46(9), 1373-1392. doi:10.1108/002517 40810911993

Pinto, M. B., \& Leal, R. P. C. (2013). Ownership concentration, top management and board compensation. Revista de Administração Contemporânea, 17(3), 304-324. doi:10.1590/S1415-65552013000300004

Ribeiro, H., Muritiba, S., Muritiba, P., \& Domingues, L. (2012). Entender para progredir: Análise da pesquisa em governança corporativa. Gestão Contemporânea, 9(12), 11-42.

Rindova, V. P. (1999). What corporate boards have to do with strategy: A cognitive perspective. Journal of Management Studies, 36(7), 953-975. doi:10.1111/1467-6486.00165

Santos, R. C., Orso, L. E., Lizote, S. A., \& Marcon, R. (2018). Board of directors: The perspective of independents in the performance of private organizations? Evidences in Brazil. Revista de Administração Mackenzie, 19(4), 1-27. doi:10.1590/1678-6971/eramf180003

Silveira, A. D. M. (2015). Governança corporativa no Brasil e no mundo: Teoria e prática (2a ed). Rio de Janeiro: Elsevier.

Silveira, A. D. M., Barros, L. A. B. D. C., \& Famá, R. (2003). Estrutura de governança e valor das companhias abertas brasileiras. Revista de Administração de empresas, 43(3), 50-64. doi:10.1590/S0034-75902003000300005

Tranfield, D., Denyer, D., \& Smart, P. (2003). Towards a methodology for developing evidence-informed management knowledge by means of systematic review. British Journal of Management, 14(3), 207-222. doi:10. $1111 / 1467-8551.00375$ 
Van Ees, H., Gabrielsson, J., \& Huse, M. (2009). Toward a behavioral theory of boards and corporate governance. Corporate Governance: An International Review, 17(3), 307-319. doi:10.1111/j.1467-8683.2009.00741.x

Wageman, R. (1995). Interdependence and group effectiveness. Administrative Science Quarterly, 40(1), 145-180. doi:10.2307/2393703

Zahra, S. A., \& Pearce, J. A. (1989). Boards of directors and corporate financial performance: A review and integrative model. Journal of Management, 15(2), 291-334. doi:10.1177/014920638901500208

Zona, F., \& Zattoni, A. (2007). Beyond the black box of demography: Board processes and task effectiveness within Italian firms. Corporate Governance: An International Review, 15(5), 852-864. doi:10.1111/j.1467-8683.2007. 00606.x

\section{AUTHOR NOTES}

Tobias C. Parente, Ph.D from the School of Economics, Business and Accounting (FEA), University of São Paulo (USP); Cláudio A. P. Machado Filho, Ph.D from the School of Economics, Business and Accounting (FEA), University of São Paulo (USP).

Tobias C. Parente is now professor at the Graduate Program in Management of the Ibirapuera University (Unib); Cláudio A. P. Machado Filho is now professor at the School of Economics, Business and Accounting (FEA) of the University of São Paulo (USP).

Correspondence concerning this article should be addressed to Tobias C. Parente, Avenida Interlagos, 1329, 4 andar, Chácara Flora, São Paulo, São Paulo, Brazil, CEP 04661-100.

E-mail: tcparente@gmail.com

EDITORIAL BOARD

Editor-in-chief

Gilberto Perez

Associated Editor

Antonio Zoratto Sanvicente

Technical Support

Vitória Batista Santos Silva
EDITORIAL PRODUCTION

Publishing Coordination

Jéssica Dametta

Layout Designer

Emap

Editorial Intern

Paula Di Sessa Vavlis

Graphic Designer

Libro
Language Editor

Daniel de Almeida Leão 